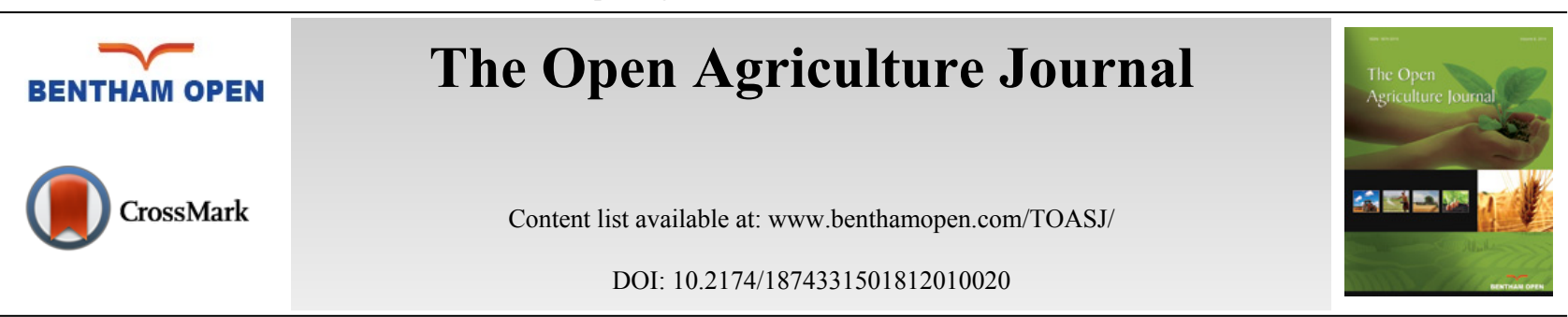

REVIEW ARTICLE

\title{
Managing Agricultural Research for Prosperity and Food Security in 2050: Comparison of Performance, Innovation Models and Prospects
}

Jane G. Payumo ${ }^{1, *}$, Shireen Assem ${ }^{2}$, Neeru Bhooshan ${ }^{3}$, Hashini Galhena ${ }^{4}$, Ruth Mbabazi ${ }^{4}$ and Karim Maredia $^{4}$

${ }^{I}$ Center for Global Connections, College of Agriculture and Natural Resources, Michigan State University, East Lansing, MI, USA 48824

${ }^{2}$ Agricultural Genetic Engineering Research Institute, Giza, Egypt 12619

${ }^{3}$ Indian Agricultural Research Institute, New Delhi, India 110012

${ }^{4}$ World Technology Access Program, Department of Entomology, College of Agriculture and Natural Resources, Michigan State University, Michigan, MI, USA 48824

Received: May 29, 2017

Revised: November 26, 2017

Accepted: January 11, 2018

\section{Abstract:}

Background:

Agriculture faces unprecedented developmental challenges globally. At the same time, rapid advances in agricultural research and innovation at the global, regional and national levels, offer unprecedented opportunities, improving performance across the entire agriculture product value chain.

\section{Objective:}

This paper highlights a multi-case study on six emerging economies in Asia and Africa and representative institutions, where opportunities for agricultural-led development are being explored to address pressing global challenges and transform agriculture into a vibrant and competitive sector.

\section{Methods:}

Drawing from secondary data and using a case study approach, this paper provides an overview and benchmarking of agricultural R\&D indicators and policies at the country and institutional levels.

\section{Results:}

Findings reveal varying levels of agricultural development and successes of the six countries: Philippines, India, Sri Lanka, Egypt, Uganda, Kenya, in terms of agricultural performance, R\&D investments and implementation of policies in managing modern agricultural innovations, intellectual property, technology transfer and public-private sector partnership in research and economic development. The paper presents some best practices and suggested measures that may be useful references for emerging economies and institutions with similar interests and initiatives to integrate agricultural research and technology transfer.

\section{Conclusion:}

Current successes and learning reveal changing and improving capacities in research and technology transfer in selected countries. However, sustaining success will require active policies to govern and promote investment in agricultural research and innovation, strategic partnerships for translating research to practice, and continuous capacity building and human resource development remain to be key ingredients for sustaining such success in addressing local and global problems in agriculture.

\footnotetext{
* Address correspondence to this author at the Center for Global Connections, College of Agriculture and Natural Resources, Michigan State University, East Lansing, MI, USA 48824; Tel: +15174321639; E-mail: payumoja@msu.edu
} 
Keywords: Agricultural development, Agricultural research, Emerging economies, Innovation, Technology transfer, Research management.

\section{INTRODUCTION}

Agriculture in the $21^{\text {st }}$ century will continue to face multiple, inter-connected challenges all over the world. It must produce more food to feed a growing population [1] characterized by changing consumption patterns, and dietary and nutritional preferences. Food and Agriculture Organization (FAO) conservatively projected that if the global population reaches 9.1 billion by 2050 , world production will need to rise by $70 \%$, and food production especially in the developing world will need to double. In Africa, which will make up a greater share of the global population, demand may get tripled by 2050 [2].

The global food production can be affected by several factors, for example, limiting arable land base, rising input costs, aging irrigation infrastructure, postharvest management losses, etc [3, 4]. The increasing interdependence between agricultural and energy sectors is also expected to interfere with global food production targets and may lead to greater competition between production for human consumption and for energy utilization $[5,6]$. Conversion of agricultural land for biofuels production is placing pressure on increasing productivity per unit of land and food prices, and has sparked large debate about global land use [7,8]. There are also rising concerns about the impact of climate disruptions to agricultural productivity. The newest projections of the impacts of climate change suggest quite dramatic negative impacts on crop and livestock production in much of the developing world, from increased stress due to weeds, insect pests, and other climate change induced stresses [9 - 11].

Beyond addressing the challenges related to food and feed, nutrition and energy security, agriculture must also continue to be the key instrument to reducing poverty and overall growth and development of countries. World Bank's latest data revealed that the agriculture sector contributes as much as 40 percent to gross domestic product (GDP), hence, contributing substantially to the national income in most developing countries [12].

About $70 \%$ of the poor in developing countries live in rural areas in Asia and Africa and derive significant parts of their livelihood and employment from agriculture and related activities. In response to growing global demand for agricultural and food products, agriculture sector in these countries is also playing an important role in the international and regional markets. African and South Asian countries, for instance, although in earlier stages, have been relatively successful in expanding production and exports of some commodities such as coffee, tea and rice in the world market $[13,14]$.

Developing countries or emerging economies have made great strides in promoting agriculture-led development to achieve the targets for Millennium Development Goals (MDGs) and improvement in the state of food insecurity $[1,15]$. Despite being a large country, India, for instance, has secured self-sufficiency and food security but also positioned itself as an important exporter of agriculture commodities. Uneven progress and shortfalls in overall agricultural development, however, call for more work to eradicate global hunger and achieve food security; as defined in the expanded MDGs, now called 17 Sustainable Development Goals (SDGs). SDGs now include targets for alleviating extreme poverty and hunger, improving health and education, promoting gender equality, reducing environmental degradation, cooperation for mitigating and addressing negative effects of climate change, and fostering economic growth and innovation.

Over the years, public Agricultural Research and Development (R\&D) from government, non-profit and higher education sectors has been a key component in addressing many of agricultural challenges and transforming global agriculture into a vibrant and productive sector. Public agriculture $R \& D$ created an impressive record in terms of contributions to generating discovery, innovation and policies. It also proved to be one of the most effective forms of public investment to modernize agriculture [16, 17]. The implementation of research-based technologies and agricultural methods such as improved crop varieties by public breeding institutions and integrated pest management contributed to incremental production that contributed in balancing the food demand-supply equation in many parts of Asia [18 - 21]. These innovations have been a cornerstone in the implementation of agriculture worldwide. Sustainable management of existing technologies and development of new, cost-effective agricultural innovations from the public sector and other sources (industry, non-governmental organizations and local farming groups) are also encouraged to meet the multi-faceted $21^{\text {st }}$ century challenges of agriculture.

The above scenarios, along with how emerging economies that depend on agriculture, especially in Asia and Africa have responded and are preparing for the current and emerging challenges of agriculture, triggered and guided this 
research. This study, hence, aims to provide an overview and comparison of these countries in terms of designing policies for a path to long-term agricultural prosperity and sustainable food security. This research also aims to provide an overview and comparison on how these countries and representative institutions are strategically managing research to develop modern food and agriculture innovation. The presentation of selected institutions in this research aims to highlight the role of institutions in fostering, nurturing, promoting and facilitating effective public agricultural research to contribute in agriculture-led development objectives. Good institutions, good governance and good leadership, when they are available, accessible and when the outcomes can be utilized by the agricultural stakeholders, can lead to effective policies and initiatives to select right priorities for research and development, manage science and innovation through intellectual property mechanism for instance, and deliver the impact of agricultural development. Fig. (1) provides an illustration of this relationship. This aligns with the currently dominant view by many authors [22 - 24] that good institutions are the ultimate determinants of a more effective economic development of a country or a region. It is hoped that findings may facilitate deeper analysis of current trends in agricultural research investments and capacity, identification of gaps and setting of future investment priorities. Institutional best practices, key actions, and recommendations presented in this paper can also help inform research, policy and practice to help catalyze similar efforts in other emerging countries and expand overall development for global agriculture in the $21^{\text {st }}$ century.

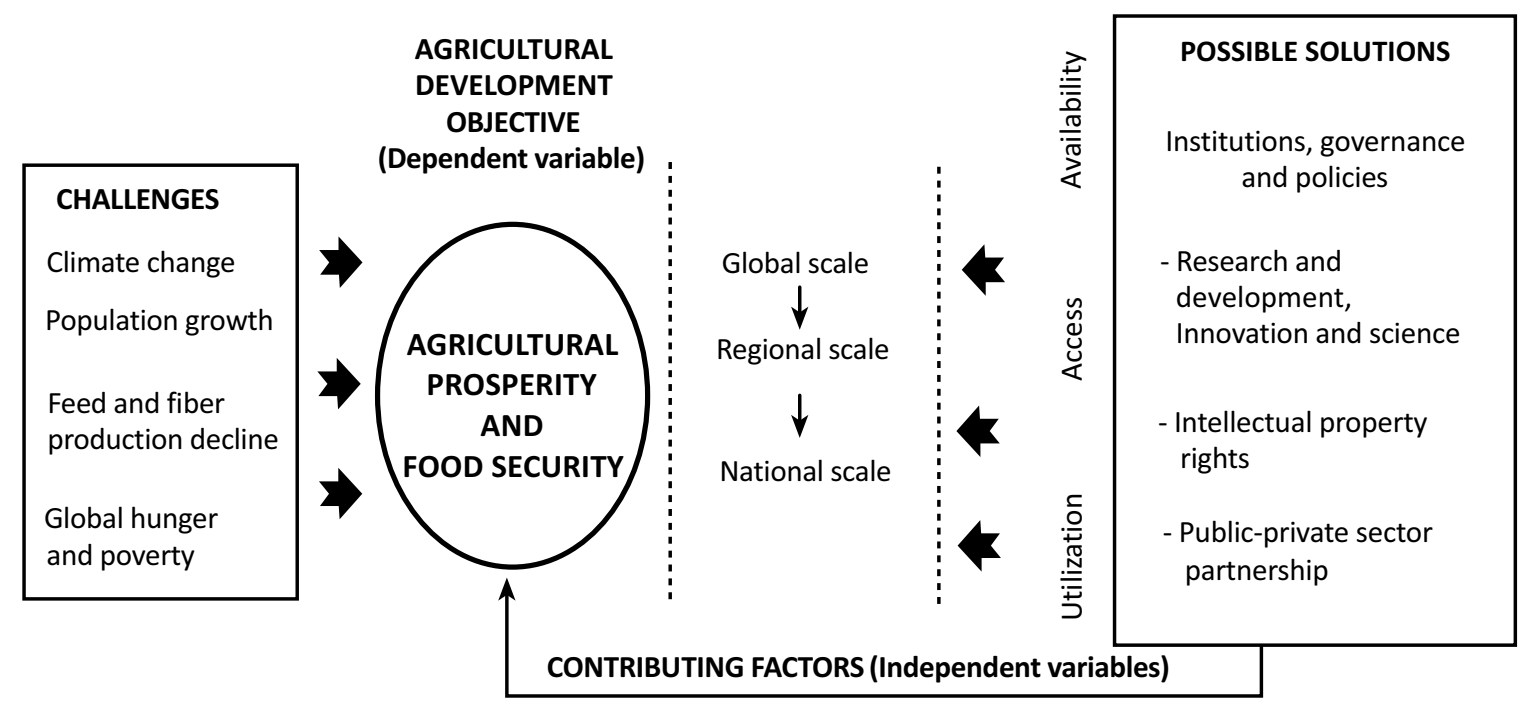

Fig. (1). Theoretical framework that guided the direction for the research and $\square$ implementation of this study.

\section{OBJECTIVES AND METHODOLOGY}

This research focused on mapping and benchmarking national agricultural performance and policies of six emerging economies in the world, namely: Southeast Asia (Philippines, India and Sri Lanka), Sub-Saharan African (Uganda and Kenya) and Middle East (Egypt). The approach adopted was to look for shared characteristics and common features of the six countries beginning with economy-wide agriculture performance and compare the countries using selected indicators that can help define the state of agricultural prosperity and food security in these countries (Table 1). Fig. (2) provides the framework that guided the comparative analysis of the six countries; the selection of the various quantitative and qualitative indicators was guided by the previous studies. Data for each of the indicators were collected from various secondary sources and agricultural data databases mainly provided by the World Bank and Food and Agriculture Organization.

Table 1. Metrics and indicators used to compare the state of agricultural prosperity and food security in select countries.

\begin{tabular}{|c|c|}
\hline Metric & Definition \\
\hline $\begin{array}{c}\text { Growth in agriculture share of gross domestic } \\
\text { product (agricultural GDP) }\end{array}$ & $\begin{array}{c}\text { growth in the share of the country's GDP derived from agriculture, measured in terms of } \\
\text { purchasing power parity index }\end{array}$ \\
\hline \multicolumn{2}{|l|}{ Agricultural production (cereals and pulses) } \\
\hline Area harvested & $\begin{array}{l}\text { total number of hectares of specific crop in a specific production season that are actually } \\
\text { harvested for use }\end{array}$ \\
\hline Yield & harvested production per unit of harvested area for crop products \\
\hline
\end{tabular}


(Table 1) contd....

\begin{tabular}{|c|c|}
\hline Metric & Definition \\
\hline Agricultural R\&D spending & $\begin{array}{l}\text { research expenditure which includes remuneration-related, operating and program expenditures } \\
\text { and capital investments }\end{array}$ \\
\hline \multicolumn{2}{|l|}{ Agricultural R\&D staffing } \\
\hline Modern biotechnology & $\begin{array}{l}\text { Yes if modern biotech research is active, otherwise No } \\
\text { Yes is country is commercializing biotech crops, otherwise No } \\
\text { Yes if country has a current biosafety policy, otherwise No }\end{array}$ \\
\hline IP and technology transfer & Yes if the country has IP and TT laws and policies, otherwise No \\
\hline
\end{tabular}

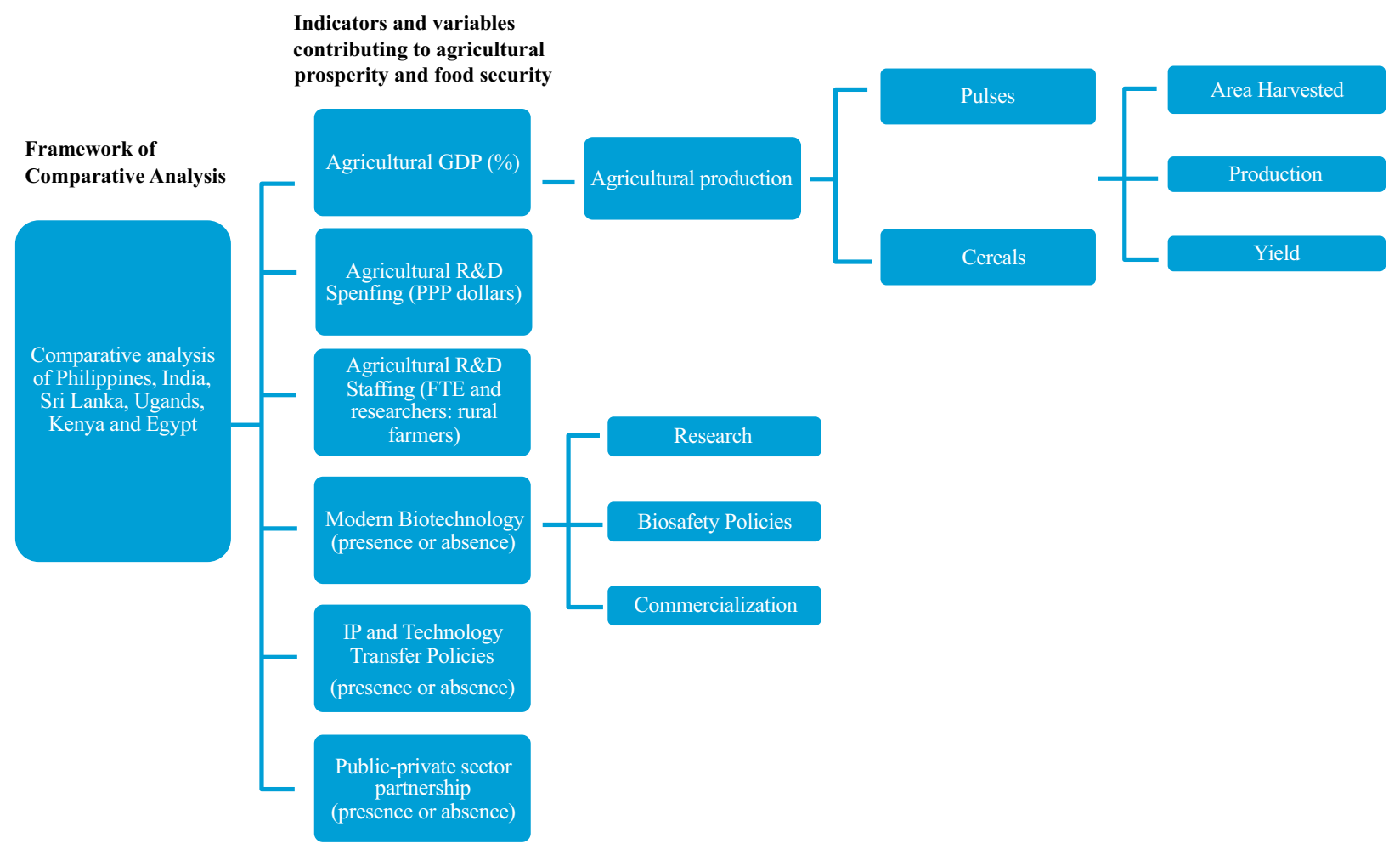

Fig. (2). Framework that guided the comparative analysis for the agricultural performance of Philippines, India, Sri Lanka, Uganda, Kenya and Egypt.

The purpose of the country overview and comparison was to simply see if the countries chosen for this research were similar or different in terms of socio-economic respects and national policy initiatives. For quantitative indicators, the growth, whether positive or negative, was determined and calculated using compound annual growth rate. Qualitative indicators indicated the presence or absence of research, policies and laws.

This study did not attempt to establish causality or to quantify the relationship illustrated in our theoretical framework and between the various indicators and agricultural prosperity and food security. The country overview of the six countries was meant to inform the design and selection of institutional case studies that contributed to the success of the six countries, and can be used to support and illustrate the important roles of institutions in managing public agricultural research, agriculture-led development objectives, and overall economic development at the global, regional and national levels

\section{BENCHMARKING AGRICULTURE PERFORMANCE OF THE SIX COUNTRIES: RESEARCH TO PRACTICE FOR SUSTAINABLE AGRICULTURAL DEVELOPMENT}

All countries except, Uganda, belong to lower middle-income groups and depend on agriculture for national income. The agricultural share of GDP of the six countries ranged from 9\% (Sri Lanka) to 27.64\% (Kenya). The relative importance of agriculture with the economy of countries, however, has changed over the years with a declining trend noted with half of the countries. Table 2 presents an overview of the share of agriculture in the economies of these countries, including growth in cereal and pulses production. The annual harvested area for staple foods namely, cereals and pulses, has increased across the countries except for India. Except Egypt, all countries had improvement in yield for 
both cereals (total) and pulses. Egypt, however, has recorded the highest average yield across the countries for the tenyear period.

Table 2. Share and growth of agricultural GDP and cereal and pulses production, 2006-2014.

\begin{tabular}{|c|c|c|c|c|c|c|}
\hline Country & \multirow{2}{*}{ Income Group $^{1}$} & \multirow{2}{*}{ Agricultural GDP } & $\mathbf{2}(\%)$ & \multicolumn{2}{|c|}{ Cereals (Total) Production } & \multicolumn{2}{|c|}{ Pulses Production } \\
\cline { 4 - 7 } & & & Area Harvested (M ha) & Yield (t/ha) & Area Harvested (M ha) & Yield (t/ha) \\
\hline Philippines & LMI & $12.09(-)$ & $7.13(+)$ & $3.75(+)$ & $0.08(+)$ & $0.87(+)$ \\
\hline India & LMI & $18.25(-)$ & $99.53(\mathrm{NC})$ & $3.06(+)$ & $26.15(-)$ & $0.71(+)$ \\
\hline Sri Lanka & LMI & $8.85(\mathrm{NC})$ & $1.05(+)$ & $4.11(+)$ & $0.02(-)$ & $1.24(+)$ \\
\hline Egypt & LMI & $12.79(-)$ & $3.15(+)$ & $7.97(\mathrm{NC})$ & $0.10(-)$ & $3.40(\mathrm{NC})$ \\
\hline Uganda & LI & $26.28(\mathrm{NC})$ & $1.69(+)$ & $2.13(+)$ & $0.97(+)$ & $0.93(+)$ \\
\hline Kenya & LMI & $27.6(+)$ & $2.48(+)$ & $1.76(+)$ & $1.43(-)$ & $0.59(+)$ \\
\hline
\end{tabular}

${ }^{1}$ Income group classification based on classification by World Bank List of Economies (World Bank, 2016); LMI = Low Middle Income, LI = Lower Income.

${ }^{2}$ The growth in agricultural GDP, cereal and pulses production were calculated using compound annual growth rate (CAGR). The (+/-) indicates the positive/negative growth trend of countries in various indicators; $\mathrm{NC}=$ not computed.

Sources: Compiled by authors based on country-level data from secondary sources [12, 40].

Additionally, we analyzed the performance of countries in terms agricultural R\&D investments, policies and regulations. This study considered the following variables: 1) public agricultural R\&D spending and staffing; (2) modern agricultural innovations (e.g. modern biotechnology) to complement conventional plant breeding and seed production programs; (3) intellectual property (IP) and technology transfer (TT) management policies at national and institutional levels; and (4) public-private partnership in research and economic development. These indicators are some of the hotly debated topics affecting the management of agricultural research to support sustainable agricultural development in the developing countries.

\subsection{Agricultural R\&D Spending and Staffing}

Serious investment in the agricultural R\&D sector will help ensure the development of technologies and practices to ensure food security and prosperity in the coming decades [25]. Sustained agricultural research funding and expertise will likewise ensure institutional growth, stability and efficacy. Table 3 presents Agricultural Science and Technology Indicators (ASTI) [26] used for analyzing research funding and expertise. Purchasing Power Parity (PPP) index, which converts current GDP prices in individual countries to a common currency, served as proxy for agricultural R\&D spending. Agricultural spending relative to agricultural GDP also served as proxy for agricultural R\&D spending. FullTime Equivalents (FTE) and the proportion of researchers per million rural farmers served as indicators for staffing for the six countries. FTE considers the proportion of time researchers spent on R\&D activities [26].

Table 3. Agricultural R\&D Spending and Staffing for the Six Countries, 2006-2014.

\begin{tabular}{|c|c|c|c|c|}
\hline \multirow{2}{*}{ Country } & \multicolumn{2}{|c|}{ Agricultural R\&D Spending } & \multicolumn{2}{c|}{ Staffing } \\
\cline { 2 - 5 } & $\begin{array}{c}\text { Total Spending } \\
\text { (million 2011 PPP dollars) }\end{array}$ & $\begin{array}{c}\text { Public Agricultural R\&D } \\
\text { Spending as a Share of } \\
\text { Agricultural GDP (\%) }\end{array}$ & $\begin{array}{c}\text { Total Researchers (FTE) } \\
\text { Agricultural Researchers per Million } \\
\text { Farmers (Economically Active Rural } \\
\text { Population) }\end{array}$ \\
\hline Philippines & $133.75(+)$ & $0.33(+)$ & N/A * & $11069(-)$ \\
\hline India & $3947.20(+)$ & $0.41(+)$ & $646(+)$ & $13(-)$ \\
\hline Sri Lanka & $55.98(-)$ & $0.29(-)$ & $8224(+)$ & $38(+)$ \\
\hline Egypt & $513.57(+)$ & $0.40(-)$ & $350(+)$ & $183(+)$ \\
\hline Uganda & $123.75(+)$ & $1.18(+)$ & $1121(+)$ & $12(+)$ \\
\hline Kenya & $254.36(+)$ & $0.98(-)$ & $35(+)$ \\
\hline
\end{tabular}

The growth in agricultural R\&D spending and staffing were calculated using CAGR. The (+/-) indicates the positive/negative growth trend of countries in these indicators. * N/A = not available, Philippines did not have panel data on total researchers; hence, not presented along with agricultural researchers per million farmers. Sources: Compiled by authors based on country-level data from ASTI indicators and secondary sources $[12,40]$.

During 2006-2014, total agricultural spending by the six countries has increased except for Sri Lanka. During this period, India had the highest expenditure, averaging 4 billion PPP dollars per year and growing at an average annual rate of $9 \%$. Sri Lanka had the least level of investment at 55 million PPP dollars and its level of investment has declined over the years. Meanwhile, during the same period, agricultural research spending of the six countries relative to their country's agricultural GDP, ranged from $0.29 \%$ to $1.18 \%$ on public agricultural R\&D on average for every dollar of 
agricultural GDP. Philippines, India and Uganda had an increasing trend of agricultural spending while Egypt, Sri Lanka and Kenya had a declining trend during the last ten years. Uganda had the highest research intensity ratio while Sri Lanka had the lowest.

As shown in Table 3, the FTE researchers for all countries except India has increased during the period 2006-2014 and grew at an average annual rate of 1-5\%. The countries employed about 300-12,000 FTE researchers during the last decade. The ratio of FTE researchers to economically active rural population for all countries, except for India has also increased over the years. Egypt employed the most number of researchers at 183 FTE researchers per million farmers while Sri Lanka had the least.

\subsection{Modern Biotechnologies}

With the success and rapid rise of modern biotechnology in North American (e.g. U.S.) markets, various groups from government, non-government, and international organizations have recognized its potential benefit to help increase food production and meet the global food needs by 2050. Currently, biotechnology crop-based tools are being used to complement traditional breeding programs to develop a new generation of food crops that are resistant to droughts, floods, pests and diseases [27, 28]. These tools allow for the transfer of desirable genetic information from species, which can be unrelated to the plant, to develop a commercially viable new variety of crop. They are also being used to fortify crops to address vitamin A deficiency in undernourished populations [29, 30] and enhance crops to provide alternative sources of biofuels [31].

Over the last few years, Philippines, India, Sri Lanka, Egypt, Uganda and Kenya are among the countries that positively responded to benefit from modern biotechnology as a tool for national development. While India and Philippines are the only countries that are commercially growing genetically modified (GM) crops, the rest of the countries are using modern biotechnology tools in R\&D to enhance crop productivity and diversity, reduce environmental impacts of agricultural production and promote market competitiveness. Now, research institutions and universities in the six countries apply modern biotechnology for selection and breeding of new varieties of plants, biofertilizers and bio pesticides, and production of GM crops with resistance to harmful pests and diseases. These institutions also use few biotechnologies, including microbial, cell biology, molecular marker, and genomics for many agricultural crops, and participate actively in educating the public on the safe and responsible use of these modern biotechnology tools. In 2015, the commercial planting of GM crops has steadily increased with more than 11 million hectares and 800,000 hectares planted to GM crops in India and Philippines (both considered "mega countries"), respectively [32]. Other GM traits are in the commercialization pipeline in these countries and in Egypt. Uganda and Kenya have approved the confined field trials of GM crops while Sri Lanka approved risk assessment laboratory tests for GM traits. The integration of modern biotechnology crops with precision agricultural technologies - a broad suite of technologies and practices that can help farmers use the right farm inputs, in the right amount at the right time for each field and crop, is also increasingly discussed as part of the countries' (e.g. India and Philippines) objectives of agricultural prosperity, food security and sustainable agriculture.

National policies and regulations on biotechnology and biosafety and membership of the six countries to international treaties (e.g. Cartagena Protocol on Biosafety) guide the adoption, commercialization and the safe use of GM crops in the six countries. The Philippines, which was one of the first Asian countries to establish a biotechnology R\&D program, institutionalized modern biotechnology as a tool to modernize agriculture and fisheries sectors. The country enacted the Agriculture and Fisheries Modernization Act of 1997 and complemented with the Department of Agriculture's (DA) Administrative Order (AO) No. 8, which further support the use and regulation of modern biotechnology research. This AO is for expansion to address risk assessment. Currently, the National Biosafety Frameworks of Kenya and Uganda are designed for enhancements. Capacity building efforts to exercise effective regulatory oversight are continuous in India, Egypt and Sri Lanka. India, realizing that biotechnology has the potential to be a globally transformative intellectual enterprise, has renewed its national biotechnology development strategy 2015-2020. The country's national biotechnology development strategy aims to launch major, well-directed effort backed by significant investment for generation of biotech products, processes and technologies to enhance efficiency, productivity, safety and cost-effectiveness of agriculture, food and nutritional security, and biofuel. Table 4 provides an overview of the status and developments of modern biotechnology in the six countries. 
Table 4. Status of Biotech R\&D, Biosafety and IP/TT Policies in Philippines, India, Sri Lanka, Egypt, Uganda and Kenya.

\begin{tabular}{|c|c|c|c|c|c|c|c|}
\hline \multirow[b]{2}{*}{ Country } & \multicolumn{3}{|c|}{ Modern Biotechnology } & \multicolumn{2}{|c|}{ Biosafety Regulation } & \multicolumn{2}{|c|}{ IP/TT Policies } \\
\hline & Type of Biotechnology Research & $\begin{array}{c}\text { Global Area } \\
\text { of Biotech } \\
\text { Crops } 2015\end{array}$ & $\begin{array}{c}\text { GM Traits } \\
\text { in the } \\
\text { Pipeline }^{\text {a }}\end{array}$ & $\begin{array}{l}\text { National } \\
\text { Laws }\end{array}$ & $\begin{array}{c}\text { International } \\
\text { Treaty } \\
\text { Agreement }\end{array}$ & $\begin{array}{l}\text { National } \\
\text { Laws }\end{array}$ & $\begin{array}{c}\text { International } \\
\text { Treaty } \\
\text { Agreements }\end{array}$ \\
\hline Philippines & $\begin{array}{c}\text { microbial, cell biology, molecular marker, } \\
\text { genomics, diagnostic }\end{array}$ & $\begin{array}{l}0.8 \text { million } \\
\text { ha }\end{array}$ & 88 & Yes & Yes & Yes & Yes \\
\hline India & $\begin{array}{c}\text { microbial, cell biology, molecular marker, } \\
\text { genomics, diagnostic }\end{array}$ & $\begin{array}{l}11.6 \text { million } \\
\text { ha }\end{array}$ & 11 & Yes & Yes & Yes & Yes \\
\hline Sri Lanka & $\begin{array}{c}\text { microbial, cell biology, molecular marker, } \\
\text { genomics, diagnostic }\end{array}$ & - & - & No* & Yes & - & Yes \\
\hline Egypt & $\begin{array}{c}\text { microbial, cell biology, molecular marker, } \\
\text { genomics, diagnostic }\end{array}$ & - & 1 & No & Yes & Yes & Yes \\
\hline Uganda & $\begin{array}{c}\text { microbial, cell biology, molecular marker, } \\
\text { genomics }\end{array}$ & - & - & No* & Yes & - & Yes \\
\hline Kenya & $\begin{array}{c}\text { microbial, cell biology, molecular marker, } \\
\text { genomics }\end{array}$ & - & - & Yes & Yes & - & Yes** \\
\hline
\end{tabular}

${ }^{a}$ Data on area of biotech crops and GM traits in the pipeline were obtained from GM approval database of the International Services for the Acquisition of Agri-Biotech Applications.

${ }^{\mathrm{b}}$ The Cartagena Protocol on Biosafety to the Convention on Biological Diversity is currently the only international agreement that exist related to the safe handling, transport and use of Living Modified Organisms (LMOs) resulting from modern biotechnology that may have adverse effects on biological diversity, taking also into account risks to human health.

${ }^{\mathrm{c}}$ International agreements on IP include WIPO-administered treaties, WTO-TRIPS and ITPGRFA.

* Sri Lanka and Uganda have pending biosafety laws and undergoing government review.

** Kenya is a member of UPOV and does not implement a sui generis protection system for plant varieties.

\subsection{Intellectual Property Rights (IPR) and Technology Transfer (TT) Policies}

The development and deployment of modern tools such as agricultural biotechnology whether from the public sector or other sources (e.g. private sector) need a supportive environment to thrive; and IPR plays a key role in creating such an environment. Better understanding of IPR and TT is now essential for informed policy making in all areas of agricultural development. Effective IP and TT strategies at the national and institutional levels help accelerate the translation of agricultural research into practice for food and agriculture products. These circumstances are compelling countries and institutions to build a culture of IP and TT management and redefine their positions and priorities.

Protection of IPR has a long history in Philippines, India, Sri Lanka, and Egypt while the application of IP regime is growing in Kenya and Uganda. These countries directly or indirectly made intellectual property (IP) a state policy by incorporating it in their constitution or civil procedures and supported several international and regional agreements that promote the effective use of IP (Table 4). The six countries are the members of major IP agreements, including the World Intellectual Property Organization (WIPO), Trade-Related Aspects of Intellectual Property Rights (TRIPS) of the World Trade Organization (WTO) and Convention on Biological Diversity (CBD). Kenya, Philippines, Sri Lanka and Uganda are Contracting Parties to the International Treaty on Plant Genetic Resources for Food and Agriculture (ITPGRFA). The accession and signing of ITPGRFA enable countries to harmonize CBD efforts for sustainable agriculture and food security, and multilateral access to PGRFA and benefit sharing.

The six countries promulgated several national legislations parallel to the international treaties and updated their country's IP law. For instance, the IP laws of Philippines, India, Sri Lanka, Egypt, Kenya, and Uganda which provide protection for inventors, trademark owners, authors and other IP creators through patent, utility model, industrial design, copyright and related rights, geographical indications and trademark, have been updated to comply with the TRIPS provisions. Except for Kenya, which is a member of Union Internationale Pour la Protection des Obtentions Végétales (UPOV), all countries covered in this research provide sui generis (of its own kind) system protection for plant varieties and give rights to breeders.

Furthermore, the six countries also promulgated and reinforced national policies and IP ownership laws that aim to promote and speed up technology transfer and commercialization especially for public sector research. These policies and laws patterned after the provisions of U.S. Bayh Dole Act of 1980, make R\&D institutions the default owner of IPR arising from the results of government-funded research. India's Ministry of Science Technology, for instance, in 2000, issued a ruling that gave title to IP to those institutions that receive funding from the Ministry. This ruling shifted technology transfer activities away from the government to research institutions. The lead public agricultural research 
organization of India, ICAR, allows copyright ownership by researchers while asserting title to all other IPRs. This IPR mechanism opened avenues for commercialization through licensing and public-private partnerships (ICAR, 2006). Public research institutions and universities in Kenya and Uganda are increasingly adopting institutional policies and capacities to assert IP ownership and meet the basic requirements of their national IP laws. Philippines, on the other hand, has enacted its Technology Transfer Law to give the ownership of inventions to universities or research institutes, effectively leaving them free to develop their own institutional IP ownership policies.

\subsection{Public-Private Partnerships in Research and Economic Development}

Public-private partnerships are increasingly playing a role in the advancement of agricultural research. As a governance strategy, these partnerships help minimize transaction costs, and coordinate and enforce relations between partners engaged in the production of agricultural goods and services. They likewise optimize approach for social and economic development, bringing together mutual gains, efficiency, flexibility, and competence of the private sector with the accountability, long-term perspective and social interest of the public sector [33]. Commercialization of IPR enabled technologies and other expertise, through public-private partnership, which can lead to their accelerated and efficient transfer [34].

Yet a new frontier for global agriculture, public-private sector partnerships are growing and benefiting agriculture in the six countries. Many public-private partnerships take the form of collaborative research projects, either leveraging private sector investment in public research initiatives or conducting research in local varieties and landraces. In India, a new wheat variety HD 3086 licensed in 2014 had a record of 108 commercial licensees in one year. During 2007-2009, for commercialization of superfine, long grain aromatic rice hybrid Pusa RH 10, IARI established public-private sector partnership with Indian Foundation Seed and Services Association and several national and multinational companies. This partnership enhanced commercial seed availability of this hybrid to cover more than 50,000 hectares in rice area. In Kenya and Uganda, public-private sector partnership, through the facilitation of the African Agricultural Technology Foundation (AATF), also enabled farmers to access DroughtTEGO ${ }^{\mathrm{TM}}$ - WE1101, a high-yielding drought tolerant variety of maize. Egypt had similar benefit when AGERI collaborated with Pioneer Hi-Bred for the local strain of Bacillus thuringiensis (Bt). This partnership enabled AGERI to gain access to expertise to develop the local strain of Bt, educate its staff on modern biotechnology, while Pioneer Hi-Bred paid the legal costs of patenting the invention, and had access to the new $B t$ strain for use in markets outside Egypt [35]. In India and Philippines, Bt eggplant (brinjal) technology was donated directly to local researchers to help develop new crop varieties that are resistant to local pests, helping to speed up farmers' access to improved varieties. Bangladesh commercially adopted Bt eggplant while India's policy on GM food crops awaits more awareness and clearance for public release.

\section{CASE STUDIES: COMPARISON OF INNOVATION MODELS AND SUCCESS STORIES}

The National Agricultural Research Systems or Institutions (NARS or NARI) are the main source of innovation in agricultural research of the six countries and now play an even larger role in increasing food production and contributing to economic growth $[36,37]$. NARS are composed of relatively young institutions (except for India) from various national agricultural research institutes, agricultural universities, private-sector firms, NGOs and farmers' organizations. These institutions are involved in developing and testing new crop varieties and cultivars, technologies for producing planting materials, irrigation technologies, farm machinery, agronomic and IPM technologies, and postharvest technologies. For many years, however, these institutions have traditionally treated their research outcomes as public goods because of directive principles of state policy, social obligations and welfare objectives. They disseminate technological information through traditional extension systems, which are becoming obsolete in the modern technological era. The new economic and scientific contexts now require new, more complex model(s) for transferring technology to benefit the agricultural sector. This section offers multi-case study on selected NARS in public universities and research institutions in the six countries and presents how these institutions are modernizing and embracing the research and innovation challenge for agriculture-led development to benefit the general public. It also features a long-time global partnership of NARS and how this collaboration has influenced NARS in pursuing development objectives and how the partnership became a win-win scenario for both the parties.

\subsection{Managing Philippine Innovations through a Working Intellectual Property Policy: The PhilRice Case}

The Philippine Rice Research Institute (PhilRice), established in 1985 as a government corporate entity attached to the Philippine Department of Agriculture, is actively engaged in rice biotechnology R\&D and IP management to support improvement of the country's main staple. It embarks on a modest but organized effort to access and use 
modern rice biotechnology tools for various applications. These include DNA marker technology to map agronomically important traits in rice such as yield components, seedling vigor, resistance to rice tungro virus, green leafhopper, brown planthopper, and blast; molecular marker aided selection techniques for tungro virus and bacterial leaf blight (BLB); and analyze genetic diversity of rice germplasm. The institute also employs in vitro techniques to improve grain quality and generate lines with tolerance to adverse conditions (cold, salinity, drought), and Agrobacterium with particle-gun bombardment -mediated transformations to produce GM rice plants with resistance to BLB, blast and sheath blight.

PhilRice, like any other public research institution in the Philippines and across the globe, has initially evolved in a world without IPRs but sooner realized the importance of IP and TT in pushing the innovation decisions. Accordingly, the institute exerted major efforts post-TRIPS Agreement towards building its capacity to deal with IPR matters, starting in 1998 and going operational by 2003. In 2004, PhilRice was the first attached DA-agency to initiate an IPR policy, including setting up of an IP management office. The institute has also embarked on continuing IP education programs for its scientists and staff, especially issues that link modern biotechnology and IPR. Now, the institute has growing IPR interests, plus a portfolio with four patents to its credit including that for agricultural machinery for seeds, the Palayamanan model for rice farming integration, and rice wine Tapuy. The institute has more than 10 patents pending including four machines and processes, PVP protection for rice hybrid and tissue-cultured varieties, and copyright registration for more than 100 knowledge products deposited at the National Library. The institution also actively pursues licensing deals and negotiations with small and medium enterprises and regularly disburses royalty shares with its researchers and inventors. Recently, PhilRice was cited by the country's Intellectual Property Office for filing the most number of patents and Patent Cooperation Treaty applications [38].

PhilRice Tapuy, a rice product produced through traditional biotechnology methods, is one of the institutional inventions, which benefited from the PhilRice IPR policy. PhilRice Tapuy is a clear, full-bodied wine with sweet alcoholic taste and roasted almond aroma. The patent application of this invention has helped document and improved the production efficiency and quality control of this product for commercial production. The new label design for the PhilRice Tapuy has a trademark protection. Trademark protection came about after a private company attempted to copy and register the same logo for their wine. The institute's Tapuy production, sales and net income have been increasing since 2003. Now, this IP-protected product is conquering market outlets and distributors in the country like supermarkets, restaurants, canteens and coffee shops.

\subsection{AGERI's Commercialization of Biotech Product from Lab to Egyptian Market}

Established in 1992, the Agricultural Biotechnology and Genetic Engineering Research Institute (AGERI) is a premier, biotechnology research institute in Egypt and in the Middle East and North Africa (MENA). AGERI is under the umbrella of the Ministry of Agriculture and Land Reclamation and aims to promote agricultural sustainability for Egypt through the development and application of the most recent technologies for the improvement of agricultural crops for biotic and abiotic stresses and develop biotechnology products with certain traits that are value in business. AGERI also provides capacity building and training support on molecular biology technologies to researchers across Egypt and other countries in the MENA region. Two years after its establishment, AGERI established the Genetic Engineering Service Unit (GESU) in 1994 to be the commercial arm of the institute, which facilitates interaction of AGERI with private and public sector entities. GESU provides services to the research community and licenses biotechnology products to the private sector.

Over the years, GESU and AGERI have made success in the commercialization of biotech product from laboratory to the market place. One great example is the commercialization of environment friendly $B t$-based bio pesticide $\left(\right.$ AGERIN $^{\circledR}$ ). AGERIN, developed through many years of laboratory research in AGERI, has a triple activity against variety of pests affecting several crops, especially, cotton. AGERI is also now gearing up for the commercialization of its $B t$-cotton (Giza-BOLLGARDII), an Egyptian cotton variety developed via crossing of Egyptian elite germplasm to Bollgard II (Monsanto). In the pipeline are improved crop varieties that can be produced by molecular breeding, genetic modification and/or genome editing technologies; with better productivity and tolerance to biotic and abiotic stresses, suitable to be cultivated in newly reclaimed lands and could be transferred from the lab to commercial seed producers and distributors.

\subsection{Agri-preneurship and Technology Transfer in Sri Lanka's University of Colombo}

Founded in 1921, the University of Colombo is a public research university located primarily in Colombo, Sri 
Lanka. It is the oldest institution of modern higher education in Sri Lanka. One of the areas of research competence of the university is on banana R\&D. Banana is an important food and cash crop for Sri Lanka traditionally propagated through suckers. While there is a high demand for banana suckers, their supply is limited. Banana R\&D at the University of Colombo in Sri Lanka dates to mid-1990s, and focused on enhancing farmer- and consumer-preferred cultivars, evaluating improved varieties for trait stability, mass production of plants, and testing for diseases.

The university in 1998 created Institute for Agro-Technology and Rural Sciences to enable scientists to interact with rural communities to introduce and transfer agricultural technologies, skills, and expertise to promote agro-industries and entrepreneurship. Equipped with two on-site tissue culture laboratories, this center can produce a maximum of 20,000 banana plants per month sufficient to meet the local demand. The institute also conducts regular field visits, conduct trainings, and awareness programs to assist farmers. Around 5000 farmers are currently benefiting from the cultivation of tissue-cultured bananas. A study carried out by the institute reveals that this technology has contributed to increasing farm income by $15-20$ folds and has created employment and agribusiness opportunities in the region.

\subsection{Benefiting from a Three-tier IP Management Mechanism at India's Council of Agricultural Research (ICAR)}

ICAR is an apex body responsible for coordinating, guiding and managing research, higher education and extension in agriculture including horticulture, fisheries and animal sciences in India. It represents the largest NARS in the world with 101 ICAR institutes and 71 agricultural universities besides 660 farm science centers (Krishi Vigyan Kendras) and 8 zonal Agricultural Technology Application Research Institutes across the country. ICAR recognizes that research in frontier sciences, such as agro-biotechnology will require IP protection through patents, plant variety protection and other forms of IPR. In 2006, ICAR launched its key IP management policy elements together with well-versed guidelines for "Intellectual Property Management and Technology Transfer/ Commercialization". These guidelines institutionalized a 3-tier IP management mechanism for the commercialization of products and transfer of skills: 1) Agro-Technology Management Center (ATMC) at ICAR level; 2) Zonal Technology Management Centers (ZTMC); and 3) Institute Technology Management Units (ITMU) in each of the institutes. This 3-tier mechanism ensures a decentralized and empowered system, especially for weaker institutes by the ZTMC; these institutes can request technical support for commercialization and strategic decisions on IP management and technology transfer. This mechanism also ensures that ICAR keeps all IP assets and other activities/records related to IP and TT activities in various ICAR institutes.

ATMC serves as the apex unit that facilitates, coordinates and monitors the implementation of IPR and TT policies across the ICAR establishments. ZTMCs handle the pre-defined zones through their Business Planning and Development Unit (BPDU) and have regional roles in managing ICAR's IP and TT activities. A director with support staff leads the IP and TT efforts of ITMUS in each ICAR institute.

Researchers at ICAR institutions are encouraged to disclose their inventions to ITMU, which evaluates the novelty of research, patentability of the invention or respective criteria of other IPR protection (e.g. plant variety protection, trademark, design protection, etc.) and pursues IPR protection and maintenance accordingly. ICAR's IP policy gives edge to IPR protection over publication. ITMU arranges to file IPR applications while PME Units oversee publication of the research results. "Indian Council of Agricultural Research" is the applicant for all IPR applications and the inventors assign their research results to ICAR. The patent/IPR applications contain all the names of all concerned ICAR scientists who contributed to the invention or the development of plant variety. ITMU facilitates commercialization of innovative technologies via licensing agreements.

In 2011, ICAR took a step forward in partnership with the Department of Agricultural Research \& Education (DARE) of the Ministry of Agriculture, to secure, sustain and promote agricultural development in the country and international collaborators. DARE set up a for profit company, the Agri-Innovate India Ltd., for technology transfer and acts as an effective interface between ICAR and the stakeholders of agricultural development at the national, regional and global levels. After the establishment of its IPR Unit in 2001 at the council headquarters, ICAR had piled up a huge IPR portfolio by 2015-16 that included a cumulative 980 patent applications filed by its 69 institutes, 170 granted patents, 167 titles granted to plant varieties, 21 registered trademarks, and 94 copyright applications filed. A patent for rapid detection of $B t$ cry toxin in cotton was granted in four countries: China, South Africa, Uzbekistan and Mexico. The four Bt-detection kits developed and commercialized became popular all over the country with sales of US $\$ 1,045,000$. Bt-based biopesticide formulations developed by ICAR institutes were licensed to over three dozen licensees in four major cotton-growing states. 
Recently, ICAR, to innovatively reach out through the large number of android mobile users in the country, launched a mobile application "Pusa Krishi" to promote its technologies for licensing to various stakeholders from corporates to individual farmers, all served by the three tiers. ICAR has commercialized around 500 agricultural technologies, including 300 agricultural engineering products through its 3-tier mechanism of managing IP and TT. Show-how, know-how clauses of licensing agreement and inventor's involvement at all stages of product development have contributed to success in these licensing agreements.

About $30 \%$ of ICARs licensed technologies, including neem-based agrochemicals and engineering products came from the Indian Agricultural Research Institute (IARI), one of the ICAR institutes and the country's oldest, premier national Institute for agricultural research, education and extension. In the last six years, IARI through the ZTMC's BPDU has successfully commercialized around 133 agricultural technologies to 365 agro-based companies ranging from crop varieties, bio-fertilizers, post-harvest technologies, agri-chemicals, farm implements and diagnostic tools to 365 agro-based companies. A portable Soil Testing and Fertilizer Recommendation meter (STFR meter) was designed by the institute's inventors and commercialized to eight industry partners for providing the soil testing services at the farmer's doorstep. Two startup companies took up this technology for manufacturing and marketing of STFR meter. This portable machine created many benefits to the farmers and created employment opportunities to the rural youth. Nano-biotechnology based biofertilizers and micronutrients are for test marketing by a licensee. PUSA varieties and Hydrogel are similarly meeting commercial success with huge benefits to user, farmers and agro-industry.

With World Bank financed National Agricultural Innovation Project support, the ZTM \& BPD Unit IARI executed end-to-end deals with Indian MNCs and other agro-companies, including the post NAIP R\&D agreements. Currently, the Unit is implementing 'Arise 2016- launch Pad for Agri Start up' program in collaboration with the Central Ministry of Micro, Small and Medium-sized Enterprises to push agri-biotechnology and agribusiness.

\subsection{International Collaborative Approach to Capacity Building, Training and Networking on Modern Innovations, IP Management, Technology Transfer for Agriculture-led Development}

Strategic partnerships are increasingly critical in agricultural research and technological development, especially as NARS expand international collaboration goals to respond to the opportunities and challenges of a globalizing agriculture sector. Governments, development agencies and partner institutions such as in the U.S. are keen in continuing to assist the NARS in their reorientation towards agri-biotech, IPR and TT, and improving their efficiency and effectiveness.

Michigan State University (MSU), a premier land grant institution in the U.S established in 1855, and ranked among the top tier of American public institutions, has been a strategic global partner of many NARS institutions across the globe. Over the years, MSU has evolved from a single college of agriculture to a comprehensive public university with more than 15 colleges and units. As a land-grant university, MSU has a three-fold mission - research, education and outreach/extension. The outreach mission of MSU goes beyond the boundaries of Michigan and the Unites States to all over the world. MSU has a successful history of collaborative research, training and education of researchers, scientists, policy makers and others worldwide, especially in international agricultural development. Today, in Africa alone, the university has more than 60 active R\&D projects in food, agriculture, health and education.

In the past, partnerships between NARS in Asia and Africa and MSU resulted in the centers of research excellence, human resource development in technical disciplines, and access to technologies and innovation in key areas. Recent efforts focus on conducting joint collaborative research in addressing global agricultural challenges, furthering the partnerships, and pursuing advanced capacity building in creating an enabling environment to maximize the benefits of technology. Partnerships are also focused on helping NARS to govern home grown IP from setting up institutional IP policies to manage research and innovation, to filing patent applications and pursuing licensing agreements for economic development opportunities and addressing future challenges to agriculture sector.

Exemplifying the approach of many departments at MSU, the College of Agriculture and Natural Resources through the World Technology Access Program (WorldTAP), emphasizes effective knowledge access, transfer and management of innovations to ensure agriculture-led development in developing countries. MSU-WorldTAP has a long history of providing capacity building and training to NARS institutions and providing them a common platform to discuss their existing programs and plans, and develop futuristic agri-biotech, IP and TT management frames for agricultural development opportunities. It trains next the generation of researchers and research management leaders from NARS in various agricultural research areas, including agricultural biotechnology, food safety and biosafety, IP management, 
technology transfer and sustainable development. MSU-WorldTAP, in partnership with various units at MSU and funding groups, offers these programs both on campus and internationally.

In spreading the importance of IP management and technology transfer to NARS institutions, MSU-WorldTAP promotes both; conventional technology and knowledge transfer (agricultural extension service) and modern information dissemination and communication approach (IPR-led commercialization and awareness generation), through licensing and commercialization agreements, which serve as a conduit for technology transfer process to local farmers and rural communities. MSU-WorldTAP program features best practices in research management and partnerships, technology transfer and delivery systems, especially that of MSU and its collaborators. MSU Technologies (MSU-T), established in 1992, handles mainly the second approach for MSU's generated innovations and technologies. MSU-T is part of the recently established MSU Innovation Center, in collaboration with MSU Business Connect and Spartan Innovations. MSU Business Connect created in 2009 is MSU's portal for engagement with the business community and industry while Spartan Innovations established in 2012 provides incubation support and helps convert MSU innovations into successful Michigan businesses. WorldTAP training participants understand MSU's IT and TT operational processes, including enforcement of MSU's IP policy, identifying which inventions belong to MSU, distribution of royalties to MSU inventors. NARS participants also obtained training on valuation and costs strategies, patent statistics (e.g. no. of inventions disclosed per year) and data monitoring (no. of patents and royalty income), and forms of technology transfer agreements (e.g. confidential disclosure, material transfer, option and licensing). Participants also get to access many resources on best practices, educational and training materials on safe and responsible use of modern biotechnology, biosafety, IP and TT; many of these materials became useful references for NARS as they revisit and redefine their research and innovation strategies. WorldTAP-MSU exposes its international IP and TT interns to various U.S. models of IPR and TT management e.g. WARF, USDA, Seed Companies, USPTOGIPA and USPVO.

During the past 20 years, MSU-WorldTAP has trained more than 500 policy makers, administrators, researchers, lawyers, private sector personnel, and students from over 80 developing countries and NARS institutions in various aspects of IP management and technology transfer, and other areas related to technology commercialization. Many of these participants led the establishment of new institutional and national policies on IP management and the formation of new TT offices in their respective institutions. ICAR-IARI, for instance, has effectively used the learnings from international internship at WorldTAP to refine the commercialization processes at the institute and develop IP and TT management skills of ICAR scientists, MSMEs, technology incubators and young entrepreneurs. The enabling environment created through the capacity building, training and networking for IP and TT by WorldTAP created new avenues of strategic partnerships for NARS institutions especially on access and technology transfer of biological materials and other modern tools for research and plant improvement (e.g. Makerere University and National Biotechnology Development Agency for material transfer of GM soybean). Overall, the impact of WorldTAP's international IP management and TT programs has been tremendous in terms of raising awareness, building human resources and institutional capacity of NARS in managing modern biotechnology and essential policies that support implementation.

WorldTAP has also mutually benefited from these connections and has now advanced research collaborations with global NARS partners in various areas (e.g. biotech soybean R\&D partnership with Indonesia and Bangladesh funded by US Agency for International Development). It has expanded its funding profile and established wider capacity building and regional collaboration in food and biosafety regulations (e.g. MSU, African Union NEPAD Agency and 15 African countries partnership funded by the Bill and Melinda Gates Foundation). It is also facilitating licensing of MSU technologies to private companies and public-private sector partnership in developing countries [39]. Recently, MSU signed an agreement with the Indian Council for Food and Agriculture to deliberate upon issues and set agenda for international agricultural development and food security.

\section{DISCUSSION, SYNTHESIS AND WAY FORWARD}

The global agricultural development model remains challenged as poverty, hunger and food insecurity due to burgeoning population and natural, demographic and human resource constraints continue to strike the agriculture sector. As projected, the impact of global challenges will be large for developing countries or emerging economies, where agriculture is the mainstay of the population and backbone of the economy. Drawing from published reports, global databases and scholarly literature, this research adds to the existing literature on how selected emerging economies in Asia and Africa are placing themselves to address these global challenges in food security and tap 
opportunities of the $21^{\text {st }}$ century for long-term agricultural growth and prosperity. Specifically, this research features country-case studies on six developing countries: Philippines, India, Sri Lanka, Egypt, Uganda, Kenya, and comparison of the countries in terms of various indicators, including agricultural R\&D performance, investments and policies that can help transform the agricultural sector. This paper also featured a couple of institutions that are among the early innovators in these countries and highlighted best practices and models in managing agricultural research and innovations to contribute to agricultural development objectives. The country and institutional case studies provide useful insights and aspiration for other emerging economies and their respective public R\&D institutions.

This research reveals the following points and implications:

1. Agricultural Growth and Development. Half of the emerging economies: Sri Lanka, Philippines, Egypt and India are transitioning and diversifying to other sources of income to support the national economy as evidenced by the declining contribution of agriculture to the country's GDP. The agricultural production and productivity of the six countries have improved over the years as evidenced by the increasing harvested area for agricultural use and yield by and large.

2. R\&D Investment. Increased R\&D spending and staffing are noted for half of the countries studied, hence, increased commitment to agricultural R\&D. R\&D spending, however, remains an even smaller fraction of Gross National income; this must improve to stimulate agricultural growth and prosperity. All countries, except India are with increased number of research personnel critical to impactful R\&D. Investments to agricultural research, technological development and critical infrastructure as well as human resource development are central to enhancing productivity.

3. New Innovations. All six countries are open to new and improved technologies and are at various stages of adopting modern biotechnology to complement conventional tools to help meet food security targets. Although in different stages of development, they are setting up policies and initiatives to facilitate safe use, research, education and deployment of modern research and innovation from modern biotechnology. New technologies such as modern biotechnology offers to make the agriculture sector more knowledge-intensive and competitive.

4. Innovation Policies. All six countries are institutionalizing IP and TT strategies to accelerate the translation of agricultural research into practice for food and agriculture products. They are building a culture of IP and TT to redefine their positions and research priorities in the global arena. Careful implementation of these policies will enable the creation of more public-private sector partnerships in agriculture, which already started in the six countries.

5. NARS as Cornerstone of Agricultural Research. This research highlighted positive developments in institutions included in this research. Information from the case studies include: 1) the importance of a working institutional IP policy to benefit the institutions and its researchers; and 2) the use of commercialization approach to complement the traditional extension services offered by NARS to deliver service and homegrown technologies and products to farmers and other stakeholders. It also highlighted effective institutional mechanisms to track, follow through and introduce new information technology in managing research and innovation in larger research council; and 4) leveraging capacity building connections to build impactful international research partnerships and economic development opportunities.

Overall, the six emerging economies in terms of agricultural performance, R\&D investments and implementation of policies are at varying levels of development and successes. These countries are setting up priorities and programs to address global challenges in agriculture and taking up the opportunities for an agriculture-led development to move to a better growth trajectory. The five institutional cases also provide evidence that the modern approach of managing and deploying the products of public agricultural research can be worthwhile and add value to fulfilling the mission of public research institutions. Managing agricultural research and modern agricultural innovations through the IPR, and technology incubators and start up mechanisms yet require institutional changes, and challenges, when implemented properly, are helpful in conjunction with the institution's core purpose of disseminating knowledge and creating tangible contribution to society. This approach proves to be valuable tools for public research institutions to improve their networking and global partnership capabilities, increase sources of funds for research and future innovation efforts, promote economic development opportunities as well as incentivize researchers. These are all critical in delivering products and services to help transform the agricultural sector and make it more competitive in a globalizing economy.

If successes are indications of future progress and with sustainable efforts, these countries and institutions highlighted in this paper may be well on the path to achieving their development goals on food security and long-term 
agriculture-led prosperity. Additional measures are further recommended:

1. Maximize the use of information and communication (ICT) technology in managing research, innovation and agricultural development. ICT tools and decision support systems will facilitate exchanges across the broad spectrum of scientific and management disciplines. It will also facilitate integration of existing knowledge and technologies in the planning of research programs, dissemination of research results and technology adoption, data reporting, and identification of strategic global partners.

2. The globalization of science requires a next generation of agricultural research leaders that are competent and can work with multiple stakeholders and experts across disciplines, sectors and continents. A competitive workforce for the agriculture sector requires access to quality R\&D faculty, facility and financial resources, capacity building and training programs particularly management development and executive development programs, and networking and collaboration opportunities. Continuing investment to improve and sustain infrastructures, operational research expenditures, and R\&D workforce remain critical.

3. National and institutional policies and regulations (e.g. biotechnology, nanotechnology, precision agriculture, biosafety, IPR and TT) affecting agriculture help define priorities and targets but should be flexible to adjust with global developments and remain relevant. These policies and regulations should also be communicated to the public constantly to increase their awareness and acceptance of technologies and products affected by these policies and regulations.

4. Contribution of private sector to support research and innovation backed by policies and regulations to create an enabling environment that encourage public-private partnership.

5. The establishment of translational centers for agri-biotech in collaboration with state agricultural universities to take forward the production improvement research including transgenic products currently developed by public institutions, and support for business incubation infrastructure, technology validation and scale-up infrastructure for accelerated commercialization of agri-biotech products can be effective instruments for pursuing national biotechnology development strategy. All these initiatives will ensure effective regulatory oversight on GM crops, increased public confidence, effective technology transfer and increased adoption of the technology.

6. Internalization of good practices and voluntary codes of conduct in IPR and TT management matters helps the research institutions in effective and efficient implementation of national and institutional policies. International collaborations that include capacity building and internship opportunities can help improve access to relevant informational resources needed for refining good practices and institutional guidelines.

\section{CONSENT FOR PUBLICATION}

Not applicable.

\section{CONFLICT OF INTEREST}

The authors declare no conflict of interest, financial or otherwise.

\section{ACKNOWLEDGMENTS}

Declared none.

\section{REFERENCES}

[1] United Nations The Millennium Development Goals Report 2015 [monograph on the internet] 2015. Available from: http://www.un.org/millenniumgoals/2015_MDG_Report/pdf/MDG\%202015\%20rev\%20(July\%201).pdf

[2] Bodirsky BL, Rolinski S, Biewald A, Weindl I, Popp A, Lotze-Campen H. Global food demand scenarios for the $21^{\text {st }}$ century. PLoS One 2015; 10(11): e0139201.

[http://dx.doi.org/10.1371/journal.pone.0139201] [PMID: 26536124]

[3] Mottaleb KA, Mohanty S. Farm size and profitability of rice farming under rising input costs. J Land Use Sci 2015; $10(3)$ : $243-55$. [http://dx.doi.org/10.1080/1747423X.2014.919618]

[4] Ognakossan E, Affognon H, Mutungi C, Sila D, Midingoyi S-K, Owino W. On-farm maize storage systems and rodent postharvest losses in six maize growing agro-ecological zones of Kenya. Food Secur 2016; 8(6): 1-21.

[5] Fraiture C, Girodano M, Liao Y. Biofuels and implications for agricultural water use: Blue impacts of green energy. Water Policy 2008; 10(Suppl. 1): 67-81.

[http://dx.doi.org/10.2166/wp.2008.054] 
[6] Pinzi S, Leiva D, Lopez-Garcia I, Redel-Macias M, Dorado M. Latest trends in feedstocks for biodiesel production. Biofuels Bioprod Biorefin 2014; 8(1): 126-43. [http://dx.doi.org/10.1002/bbb.1435]

[7] Tomei J, Helliwell R. Food versus fuel? Going beyond biofuels. Land Use Policy 2016; (56): 320-6. [http://dx.doi.org/10.1016/j.landusepol.2015.11.015]

[8] Castiblanco C, Etter A. Biofuels as a new energy paradigm: The key points of debate after a decade. Cuad Desarro Rural 2013 ; 10(70): 69-92.

[9] D'Agostino A, Schlenker W. Recent weather fluctuations and agricultural yields: Implications for climate change. Agric Econ 2016; (47): $159-71$ [http://dx.doi.org/10.1111/agec.12315]

[10] Craparo A, Van Asten P, Läderach P, Jassogne L, Grab S. Coffee arabica yields decline in tanzania due to climate change. Agric For Meteorol 2015; (207): 1-10. [http://dx.doi.org/10.1016/j.agrformet.2015.03.005]

[11] Gustafson DI. Climate change: A crop protection challenge for the twenty-first century. Pest Manag Sci 2011; 67(6): 691-6. [http://dx.doi.org/10.1002/ps.2109] [PMID: 21432984]

[12] World Bank Open Data [homepage on the internet] 2016. Available from: http://data.worldbank.org/

[13] International Monetary Fund (IMF) (2014) Sub-saharan Africa fostering durable and inclusive growth [monograph on the internet] 2014. Available from: https://www.imf.org/en/Publications/REO/SSA/Issues/2017/02/01/Fostering-Durable-and-Inclusive-Growth

[14] International Trade Statistics - World Trade Organization [homepage on the internet 2017. Available from: https://www.wto.org/english/res_e/statis_e/statis_e.htm

[15] FAO, IFAD and WFP The state of food insecurity in the world 2015 Meeting the 2015 international hunger targets: Taking stock of uneven progress 2015. Available from: http://www.fao.org/3/a-i4646e.pdf

[16] Hazell P, Haddad L. Agricultural research and poverty reduction IFPRI 2020. Washington, D.C.: International Food Policy Research Institute 2001.http://www.ifpri.org/publication/agricultural-research-and-poverty-reduction-0

[17] Fan S, Rao N. Public spending in developing countries: Trends, determination, and impact. Washington, D.C: International Food Policy Research Institute 2003.https://ageconsearch.umn.edu/bitstream/16080/1/ep030099.pdf monograph on the internet [cited December 16, 2016]

[18] Rosegrant M, Paisner M, Meijer S. The future of cereal yields and prices: Implications for research and policy. J Crop Prod 2003; 9(1-2): $661-90$ [http://dx.doi.org/10.1300/J144v09n01 13]

[19] Alam MZ, Crump AR, Haque MM, Islam MS, Hossain E, Hasan SB. Hasan Sb, Hossain MS. Effects of integrated pest management on pest damage and yield components in a rice agro-ecosystem. Front Environ Sci 2016; 22(4): 1-10.

[20] World Bank World development report 2008: Agriculture for development 2007 [monograph on the internet]: 2007. Available from: https://siteresources.worldbank.org/INTWDR2008/Resources/WDR_00 book.pdf

[21] Stevenson JR, Villoria N, Byerlee D, Kelley T, Maredia M. Green revolution research saved an estimated 18 to 27 million hectares from being brought into agricultural production. Proc Natl Acad Sci USA 2013; 110(21): 8363-8. [http://dx.doi.org/10.1073/pnas.1208065110] [PMID: 23671086]

[22] Acemoglu D, Johnson S, Robinson J. Institutions as the fundamental cause of long-run growth handbook of economic growth. Amsterdam: North-Holland 2005; pp. 385-472.

[23] Talmaciu M. Study on the relationships between institutions, governance, and leadership and regional development policy in Romania. Procedia Econ Finance 2014; (15): 1281-8

[http://dx.doi.org/10.1016/S2212-5671(14)00589-9]

[24] Ali MS, Krammer SM. The role of institutions in economic development.economic development in the Middle East and North Africa. New York: Palgrave Macmillan 2016; pp. 1-25.

[25] Akroyd S, Smith L. Review of public spending to agriculture: A Joint DFID /World Bank study main study and country case-studies. Oxford, England: Oxford Policy Management 1999.http://www1.worldbank.org/publicsector/pe/pfma07/OPMReview.pdf monograph on the internet [cited 2017 January 12]

[26] Flaherty K, Stads G-J, Srinivasacharyulu A. Benchmarking agriclutural research indicators across Asia-Pacific. Bangkok, Thailand: International Food Policy Research Institute 2013.https://www.asti.cgiar.org/pdf/ASTI-Asia-Pacific-Regional-Synthesis.pdf monograph on the internet

[27] Pray C, Nagarajan L, Li L, Huang J, Hu R, Selvaraj K. Napasintuwong, Ora, Chandra Babu R. Potential impact of biotechnology on adaption of agriculture to climate change: The case of drought tolerant rice breeding in Asia. Sustainability 2001; 3(10): 1723-41.

[28] Hautea R, Escaler M. Plant biotechnology in asia. AgBioForum 2004; (7): 2-8.

[29] Alós E, Rodrigo MJ, Zacarias L. Manipulation of carotenoid content in plants to improve human health. Subcell Biochem 2016; 79(1): 311-43.

[http://dx.doi.org/10.1007/978-3-319-39126-7_12] [PMID: 27485228] 
[30] Beyer P, Al-Babili S, Ye X, et al. Golden Rice: introducing the $\beta$-carotene biosynthesis pathway into rice endosperm by genetic engineering to defeat vitamin A deficiency. J Nutr 2002; 132(3): 506S-10S. [http://dx.doi.org/10.1093/jn/132.3.506S] [PMID: 11880581]

[31] Huang G, Chen F, Wei D, Zhang X, Chen G. Biodiesel production by microalgal biotechnology. Appl Energy 2010; 87(1): 38-46. [http://dx.doi.org/10.1016/j.apenergy.2009.06.016]

[32] James C. Global status of commercialized biotech/gm crops: 2015 Manila, Philippines: The International Service for the Acquisition of Agribiotech Applications (ISAAA) 2016. Available from: http://isaaa.org/resources/publications/briefs/51/default.asp

[33] Ayyappan S, Chandra P, Tandon S. ICAR-industry meet agricultural transformation through public-private partnership: An interface New Delhi. New Delhi: Indian Council of Agricultural Research 2007.http://www.icar.org.in/files/Public-Private-Partnership.pdf [cited 2017 February 1]

[34] ICAR. ICAR guidelines for intellectual property management and technology transfer/ commercialization [monograph on the internet] 2006.http://www.icar.org.in/files/reports/other-reports/icar-ipmttcguide.pdf

[35] Madkour M. Egypt.Agricultural biotechnology: Country case studies: A decade of development, london. UK: CABI Publishing 2001; pp. 129-34.

[36] Food and Agriculture Organization Role of research in global food security and agricultural development [monograph on the internet] 1996. Available from: https://ec.europa.eu/jrc/sites/jrcsh/files/role-research-global-food-nutrition-security.pdf

[37] Payumo J, Sebastian L. NARES capacity in relation to international treaties and conventions on intellectual property rights, agricultural biotechnology, and plant genetic resources management. Asian J Agric Dev 2008; 4(1): 92-114.

[38] PhilRice [homepage on the Internet] 2017. Available from: http://www.philrice.gov.ph/ph-rice-institute-leads-patents-applications/

[39] Maredia K, Rakhmatov C, Herlache T, Eds. Technology transfer and commercialization, experiences of india and USA WorldTAP. East Lansing, MI: Michigan State University 2013; p. 48824.

[40] FAOSTAT Statistic Database [homepage on the internet] 2017. Available from: http://www.fao.org/faostat/en/\#home

(C) 2018 Payumo et al.

This is an open access article distributed under the terms of the Creative Commons Attribution 4.0 International Public License (CC-BY 4.0), a copy of which is available at: (https://creativecommons.org/licenses/by/4.0/legalcode). This license permits unrestricted use, distribution, and reproduction in any medium, provided the original author and source are credited. 